\title{
LEUKOCYTOSIS INTERFERENCE IN CLINICAL CHEMISTRY: SHALL WE STILL INTERPRET TEST RESULTS WITHOUT HEMATOLOGICAL DATA?
}

\author{
INTERFERENCIJA LEUKOCITOZE U KLINIČKOJ HEMIJI: DA LI ĆEMO I DALJE \\ INTERPRETIRATI REZULTATE TESTA BEZ HEMATOLOŠKIH PODATAKA?
}

\author{
Guillaume Grzych ${ }^{1,2}$, Estelle Roland ${ }^{3}$, David Beauvais $^{4}$, Patrice Maboudou ${ }^{3}$, Giuseppe Lippi ${ }^{5}$ \\ ${ }^{1} \mathrm{CHU}$ Lille, Department of Biochemistry and Molecular Biology, Laboratory of Endocrinology, \\ Metabolism-Nutrition, Oncology, Biology Pathology Center, University of Lille, F-59000 Lille, France \\ 2INSERM, UMR-1011-European Genomic Institute for Diabetes, Pasteur Institute, University of Lille, Lille, France \\ ${ }^{3} \mathrm{CHU}$ Lille, Biochemistry Emergency Department, Biology and Pathology Center, University of Lille, \\ F-59000 Lille, France \\ ${ }^{4} \mathrm{CHU}$ Lille, Hematology Department, Huriez Hospital, University of Lille, F-59000 Lille, France \\ ${ }^{5}$ Section of Clinical Biochemistry, University of Verona, Verona, Italy
}

\section{Summary}

Background: Extreme leukocytosis is known to induce remarkable variations of some clinical chemistry tests, thus leading to possible clinical misinterpretation. This study aimed to define whether also moderate leukocytosis may influence the stability of glucose and blood gases.

Methods: Blood samples are sent to the local laboratory through a pneumatic tube system. Clinical chemistry testing is routinely performed using lithium-heparin tubes (for glucose) and heparin blood gases syringes (for blood gas analysis). Stability of glucose (in uncentrifuged blood tubes) and blood gases (in syringes) was hence evaluated in samples maintained at room temperature. Results were also analyzed in 2 subgroups of samples with different leukocyte counts, i.e., those with leukocytes $<15 \times 10^{9} / \mathrm{L}$ and those with leukocytes $>15 \times 10^{9} / \mathrm{L}$.

Results: An accelerated decrease of $\mathrm{pH}$ was observed in blood gases syringes with leukocytosis (i.e., $>15 \times 10^{9} / \mathrm{L}$ ), while no difference was noted for other blood gases parameters $\left(\mathrm{PCO}_{2}, \mathrm{PO}_{2}\right)$. Spurious and time-dependent hypoglycemia was noted in uncentrifuged blood tubes of patients with leukocytosis.

Conclusions: The results of our study suggest that even modest leukocytosis (i.e., around $15 \times 10^{9} / \mathrm{L}$ ), which is

\section{Kratak sadržaj}

Uvod: Poznato je da ekstremna leukocitoza izaziva značajne varijacije nekih kliničkih hemijskih testova, što dovodi do moguće pogrešne kliničke interpretacije. Cilj ovog rada bio je da se utvrdi da li i umerena leukocitoza može uticati na stabilnost glukoze i gasova u krvi.

Metode: Uzorci krvi su poslati u lokalnu laboratoriju preko pneumatskog sistema cevi. Klinička hemijska ispitivanja se rutinski izvode koristeći litijum-heparinske epruvete (za glukozu) i heparinske gasove (za analizu gasa u krvi). Stabilnost glukoze (u necentrifugiranim epruvetama krvi) i gasova u krvi (u špricevima) je zbog toga procenjena na uzorcima koji su održavani na sobnoj temperaturi. Rezultati su takođe analizirani u 2 podgrupe uzoraka sa različitim brojem leukocita, to jest, sa leukocitima $<15 \times 10^{9} / \mathrm{L}$ i sa leukocitima > $15 \times 10^{9} / \mathrm{L}$.

Rezultati: U špricu sa gasovima u krvi sa leukocitozom (tj. $>15 \times 10^{9} / \mathrm{L}$ ) primećeno je ubrzano smanjenje $\mathrm{pH}$ vrednosti, pri čemu nije zabeležena razlika za druge parametre gasova krvi $\left(\mathrm{PCO}_{2}, \mathrm{PO}_{2}\right)$. Lažna i vremenski zavisna hipoglikemija zabeležena je u necentrifugiranim epruvetama pacijenata sa leukocitozom.

Zaključak: Rezultati našeg istraživanja ukazuju da čak i skromna leukocitoza (tj. oko $15 \times 10^{9} / \mathrm{L}$ ), koja se često

Address for correspondence:

Dr Guillaume Grzych

Laboratory of Biochemistry, Biology and Pathology Center,

Lille University Hospital,

Pr J. Leclercq Boulevard, 59037, Lille Cedex, France

Phone: +33(0)320446173

e-mail: guillaume.grzych@inserm.fr 
frequently encountered in clinical and laboratory practice, may be associated with significant variations of both glucose and $\mathrm{pH}$. This would lead us to conclude that results of these parameters shall be accompanied by those of hematologic testing to prevent clinical misinterpretation, namely with leukocyte counts.

Keywords: glucose, blood gases, preanalytical variability

\section{Introduction}

It has been convincingly shown that some clinical chemistry parameters may display spurious changes in samples with extreme leukocytosis, thus potentially disturbing both clinical decision making and patient management.

Monitoring blood glucose is essential, since hyperglycemia may be associated with many symptoms such as infections or late-onset nerve damage, while hypoglycemia may also cause serious health consequences. The basic symptoms of hypoglycemia are poorly specific and include fatigue, mood changes, difficulty in concentrating and completing mental tasks, blurred vision, extreme hunger, nervousness, headache, excessive perspiration and tachycardia. Extremely low glucose levels can trigger convulsions and coma (1). An accurate diagnosis of hypoglycemia is also essential for diagnosing metabolic diseases (2).

Glucose is usually measured in clinical laboratories using plasma, serum or whole blood samples. The term "artifactual hypoglycemia» was proposed when results of laboratory measurement do not reflect the actual blood glucose concentration, regardless of the presence of symptoms of both hypoor hyperglycemia (3). Artifactual hypoglycemia has also been related to in vitro glucose consumption by blood cells after blood sample has been drawn $(4,5)$.

Sodium fluoride is largely used as glycolysis inhibitor in fluoride tubes since it assures longer glucose stability in uncentrifuged or non-separated blood tubes. Nevertheless, lithium-heparin blood tubes without glycolysis inhibitors are very frequently used to measure glucose in clinical and laboratory practice, since it helps to reduce the number of samples drawn and minimizing blood wasting, especially in critically ill patients with severe anemia $(6,7)$.

A recent study showed that normal blood cell counts and volumes might both have an impact on glucose concentration in uncentrifuged serum and lithium-heparin blood tubes (8), while no data are available on the impact of non-leukemic leukocytosis on glucose stability in blood samples to the best of our knowledge. We suspect that the impact on glucose may be even greater with leukocytosis than with normal leukocyte counts.

Blood gases are conventionally requested as emergency tests. By measurement of dissolved gases sreće u kliničkoj i laboratorijskoj praksi, može biti povezana sa značajnim varijacijama i glukoze i $\mathrm{pH}$. To nas je navelo na zaključak da rezultati ovih parametara moraju biti propraćeni rezultatima hematološkog testiranja kako bi se sprečila pogrešna klinička interpretacija, a sve zbog broja leukocita.

Ključne reči: glukoza, gasovi u krvi, preanalitička varijabilnost

in blood and $\mathrm{pH}$, blood gas analysis provides essential clinical information for monitoring alveolar ventilation and acid-base balance (9). The stability of these parameters in blood samples is strongly influenced by storage temperature and by the possible presence of hemolysis $(10,11)$. Previous studies showed that blood gases are stable for up to 30 minutes after collection (12), while the analysis of blood gases in samples (typically syringes) after this period may yield unreliable results. Since blood gas analysis is an essential test for patients with acute conditions, and recollection of a new blood sample is not always feasible in short-stay units, blood gas analysis is occasionally carried out after the recommended 30-min stability threshold. Nevertheless, blood cells are known to gradually modify the acid-base balance over time, by consuming both oxygen and glucose (1315), and thus potentially leading to unreliable test results. A case of pseudohypoxemia in a patient with chronic lymphocytic leukemia was also identified, showing that blood gases stability is inversely correlated with the leukocyte count (16).

Therefore, the aim of this study was to define whether moderate leukocytosis may also influence the stability of some clinical chemistry parameters, namely glucose and blood gases.

\section{Materials and Methods}

\section{Patient selection and data collection}

The study population consisted of patients undergoing routine laboratory testing at Lille University Hospital. Patients received detailed information that their clinical data and/or residual blood samples could be used for research purposes after routine testing had been completed. All data were retrieved from a human biological database authorized by the French Ministry of Research (No. DC2008-642). Therefore, no written informed consent was collected from this population.

The stability of glucose was assessed in lithiumheparin tubes (4 mL BD Vacutainer ${ }^{\mathrm{TM}}$; Becton Dickinson, Franklin Lakes, NJ, United States) and blood gases in heparin syringes (3 $\mathrm{mL}$ Smiths Medical; Minneapolis, MN, United States).

To perform our study, we selected samples containing enough blood to allow repeated analyses (full draw). Samples were selected upon arrival from 
patients who had had a recent leukocyte count available. Samples were divided into 2 groups according to the leukocyte count: i.e. $<15 \times 10^{9} / \mathrm{L}$ or $>15 \times$ $10^{9} / \mathrm{L}$.

\section{Laboratory measurements}

Glucose concentrations were measured using Roche Cobas 8000® (Roche Diagnostics, RischRotkreuz, Switzerland). Blood gas parameters were measured on Radiometer ABL800 FLEX (Radiometer, Copenhagen, Denmark). White blood cell count (WBC), hematocrit and platelets count were assayed in BD Vacutainer ${ }^{T M}$ ethylenediaminetetraacetic acid tubes (Becton Dickinson, Franklin Lakes, NJ, United States), using Sysmex XN (Sysmex Corporation, Kobe, Japan).

All blood tubes and syringes were sent to the laboratory by a pneumatic tube system (PTS) (Swisslog, Switzerland) within 30 min of collection.

For glucose stability experiments, one blood sample (i.e., lithium-heparin blood tube) was collected from each patient and was immediately centrifuged after arrival at $4000 \times \mathrm{g}$ for $5 \mathrm{~min}$. Lithiumheparin tubes were maintained on a roller mixer at room temperature throughout the study to prevent sedimentation of blood cells in between measurements. Blood cells would this way continue in vitro glucose consumption and better reflect the impact of a delay in sample handling. Before each plasma glucose measurement, samples were centrifuged at $4000 \times \mathrm{g}$ for $5 \mathrm{~min}$.

Plasma glucose was successively measured at 0 , $2,4,6$ and 8 hours after the reception in the labora- tory, and its variation was compared in 2 different groups of patients, displaying WBC count $<15 \times$ $10^{9} / \mathrm{L}$ or $>15 \times 10^{9} / \mathrm{L}$.

For blood gases stability experiments, one whole blood sample (i.e., heparin blood gas syringe) was collected from each patient. Blood gas analysis was then carried out at 0,60,120 and $180 \mathrm{~min}$ after the reception in the laboratory, on the same syringe maintained at room temperature. Results were compared in 2 groups of patients, i.e., those with leukocyte counts $<15 \times 10^{9} / \mathrm{L}$ or $>15 \times 10^{9} / \mathrm{L}$. Before each measurement, the syringe was gently mixed to avoid sedimentation and kept sealed afterwards.

The local reference ranges were 65 to 100 $\mathrm{mg} / \mathrm{dL}(3.58-5.50 \mathrm{mmol} / \mathrm{L})$ for glucose and $4-10$ $\times 10^{9} / \mathrm{L}$ for WBC count.

\section{Statistical analyses}

Data analyses were performed with paired Wilcoxon ranked test and Pearson correlation using $\mathrm{R}$ software (www.R-project.com) and GraphPad Prism software v6.0. The statistical methods used included t-tests, ANOVA and regression analysis. Statistical significance was set at $\mathrm{p}<0.05$.

\section{Results}

\section{Glucose}

A total number of 64 lithium-heparin samples were included in our analysis, which were sorted according to WBC count, platelet count and hematocrit values, as shown in Table I. The baseline glucose

Table I Grouping of patients $(n=64)$ according to leukocytosis levels (threshold: $15 \times 10^{9} / \mathrm{L}$ ) and the measure of baseline glucose levels, White Blood Cells counts, Platelets counts and Hematocrit levels (Mean +/- SEM) measured in blood. Regression and correlation between glucose and time for each group, p-value obtained by Pearson t-test.

\begin{tabular}{|c|c|c|c|c|c|c|c|c|c|c|c|c|}
\hline & & Glucose & tO (mmol/L) & $\begin{array}{l}\text { White } \\
\quad\left(x^{\prime}\right.\end{array}$ & $\begin{array}{l}\text { 3lood Cells } \\
0 \% / L)\end{array}$ & Platelets & $\left(x 10^{9} / L\right)$ & Hem & atocrit (\%) & & $\begin{array}{l}\text { lucose-7 } \\
\text { Regress }\end{array}$ & $\begin{array}{l}\text { Time } \\
\text { ion }\end{array}$ \\
\hline & $\mathrm{N}$ & $\begin{array}{l}\text { Mean } \\
\text { (SE) }\end{array}$ & Min-Max & $\begin{array}{c}\text { Mean } \\
\text { (SE) }\end{array}$ & Min-Max & $\begin{array}{c}\text { Mean } \\
\text { (SE) }\end{array}$ & Min-Max & $\begin{array}{l}\text { Mean } \\
\text { (SE) }\end{array}$ & Min-Max & Slope & $r$ & $\mathrm{p}$-value \\
\hline $\begin{array}{l}\text { Low } \\
\text { Leukocytes } \\
\left(<15 \times 10^{9} / \mathrm{L}\right)\end{array}$ & 54 & $\begin{array}{c}6.32 \\
(1.39)\end{array}$ & $3.77-12.9$ & $\begin{array}{c}7.77 \\
(2.75)\end{array}$ & $0.3-14.51$ & $\begin{array}{c}249 \\
(110)\end{array}$ & 24-785 & $\begin{array}{c}31 \\
(4.8)\end{array}$ & $19.9-44.2$ & -0.34 & $\mid-0.42$ & $<0.001$ \\
\hline $\begin{array}{l}\text { High } \\
\text { Leukocytes } \\
\left(>15 \times 10^{9} / \mathrm{L}\right)\end{array}$ & 10 & $\begin{array}{c}6.32 \\
(1.49)\end{array}$ & $3.55-9.55$ & $\begin{array}{l}109 \\
(88)\end{array}$ & 15-346 & $\begin{array}{c}214 \\
(206)\end{array}$ & $13-682$ & $\begin{array}{c}27 \\
(4.3)\end{array}$ & $19.4-36.6$ & -0.63 & $\mid-0.67$ & $<0.001$ \\
\hline $\begin{array}{l}\text { Low Platelets } \\
\left(<150 \times 10^{9} / \mathrm{L}\right)\end{array}$ & 18 & $\begin{array}{c}6.93 \\
(1.83)\end{array}$ & $3.55-12.9$ & $\begin{array}{l}57 \\
(71)\end{array}$ & $0.3-346$ & $61(30)$ & $13-148$ & $\begin{array}{l}26.9 \\
(4)\end{array}$ & $19.4-42.5$ & -0.27 & $\mid-0.22$ & 0.028 \\
\hline $\begin{array}{l}\text { High Platelets } \\
\left(>150 \times 10^{9} / \mathrm{L}\right)\end{array}$ & 46 & $\begin{array}{c}6.05 \\
(1.22)\end{array}$ & $3.77-10.7$ & $\begin{array}{l}10 \\
(4)\end{array}$ & $2.7-41.26$ & $\begin{array}{c}316 \\
(109)\end{array}$ & $157-785$ & $\begin{array}{l}32.5 \\
(4.2)\end{array}$ & 23.5-44.2 & -0.39 & $\mid-0.26$ & $<0.001$ \\
\hline $\begin{array}{l}\text { Low Hematocrit } \\
(<30 \%)\end{array}$ & 32 & \begin{tabular}{|c|}
6.49 \\
$(1.49)$ \\
\end{tabular} & $3.55-14.1$ & $\begin{array}{c}37 \\
(47)\end{array}$ & $0.3-346$ & $\begin{array}{c}118 \\
(116)\end{array}$ & $13-413$ & $\begin{array}{c}26 \\
(2.3)\end{array}$ & $19.4-29.5$ & -0.31 & -0.36 & $<0.001$ \\
\hline $\begin{array}{l}\text { High } \\
\text { Hematocrit } \\
(>30 \%)\end{array}$ & 32 & $\begin{array}{c}6.16 \\
(1.27)\end{array}$ & $3.77-10.7$ & $\begin{array}{c}9.5 \\
(3.5)\end{array}$ & $3.8-40.5$ & $\begin{array}{c}300 \\
(142)\end{array}$ & 24-785 & $\begin{array}{c}36 \\
(3.1)\end{array}$ & $30.2-44.2$ & -0.41 & -0.56 & $<0.001$ \\
\hline
\end{tabular}



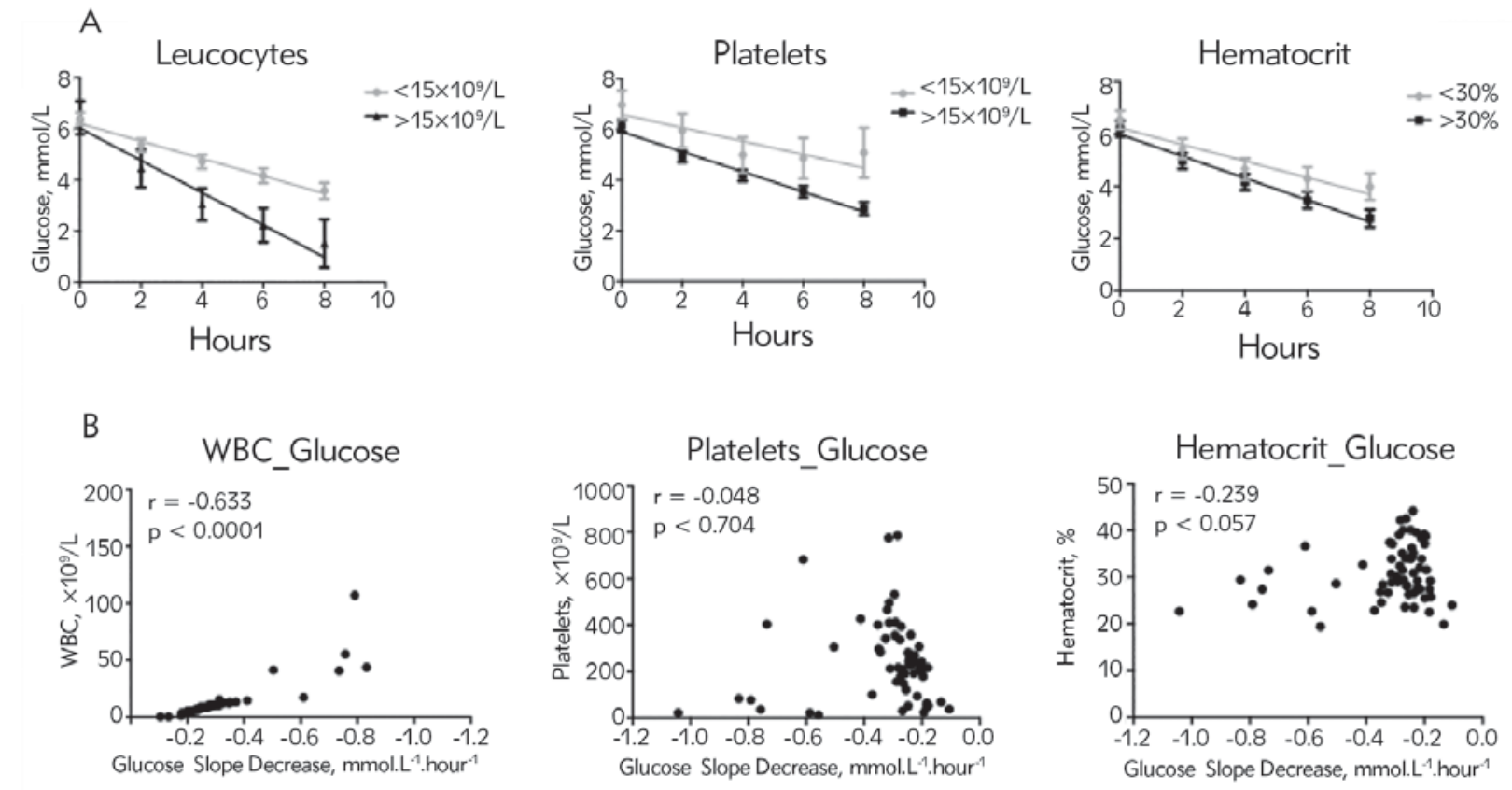

Figure 1 Glucose values (Mean +/- SEM) measured at 2 hours intervals in blood from patients with white blood cell (WBC) values $<15 \times 10^{9} / \mathrm{L}$ (gray lines) or $>15 \times 109 / \mathrm{L}$ (black lines), with platelets $<15 \times 10^{9} / \mathrm{L}$ (gray lines) or $>15 \times 10^{9} / \mathrm{L}$ (black lines), and hematocrit $<30 \%$ (grey lines) and $>30 \%$ (black lines). B. Correlation between variation of glucose (mmol.L-1.hour-1) and WBC, platelets or hematocrit.

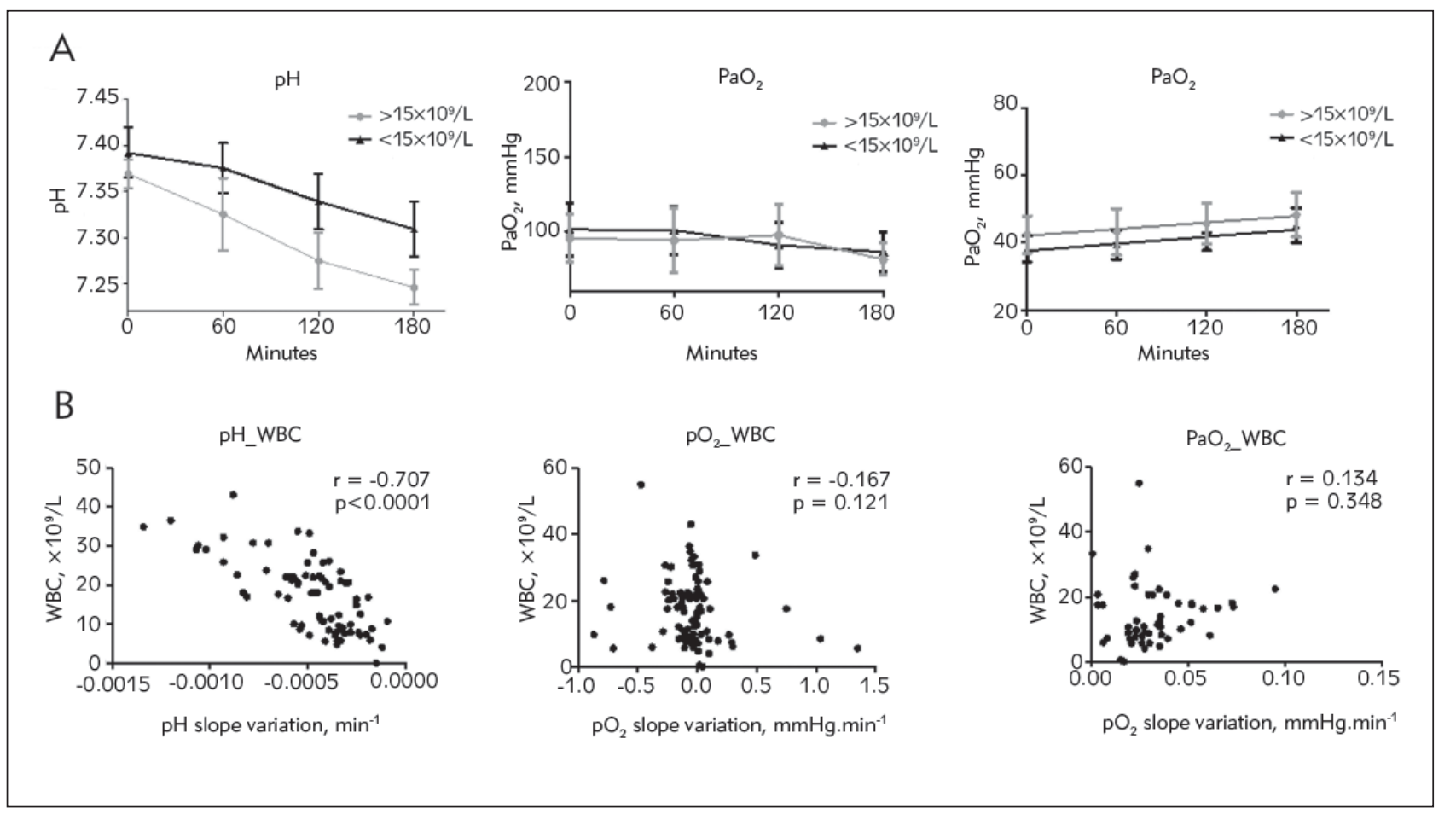

Figure $2 \mathrm{pH}, \mathrm{PaO}_{2}$ and $\mathrm{PCO}_{2}$ values (Mean $+/-\mathrm{SEM}$ ) measured at 60 minutes intervals in whole blood collected from patients with white blood cell $\left(\mathrm{WBC}\right.$ ) values $<15 \times 10^{9} / \mathrm{L}$ (black lines) or $>15 \times 10^{9} / \mathrm{L}$ (grey lines). B. Correlation between WBC count and variation of $\mathrm{pH}, \mathrm{pO}_{2}$ and $\mathrm{pCO}_{2}$ in $\mathrm{min}^{-1}$. 
Table II Grouping of patients $\left(\mathrm{n}=77\right.$ ) according to leukocytosis levels (threshold: $15 \times 10^{9} / \mathrm{L}$ ) and measure of baseline $\mathrm{pH}$, $\mathrm{PaO}_{2}, \mathrm{PCO}_{2}$ and White Blood Cells counts (Mean +/- SEM) measured in blood. Regression and correlation between time and each blood gas parameters $\left(\mathrm{pH}, \mathrm{pO}_{2}\right.$ and $\left.\mathrm{pCO}_{2}\right)$, p-value obtained by Pearson t-test.

\begin{tabular}{|c|c|c|c|c|c|}
\hline & & Low Leukocytes & $\left.\times 10^{9} / \mathrm{L}\right) \mathrm{n}=32$ & High Leukocytes & $\left(10^{9} / L\right) n=45$ \\
\hline & & Mean (SE) & Min-Max & Mean (SE) & Min-Max \\
\hline & & $7.39(0.12)$ & $6.96-7.57$ & $7.36(0.08)$ & $7.14-7.60$ \\
\hline $\mathrm{pO}_{2}$ t0 & & $101(32)$ & $33-333$ & $96(40)$ & $33-302$ \\
\hline $\mathrm{pCO}_{2}+\mathrm{C}$ & & $36(6)$ & $22-78$ & 46 (14) & $18-94$ \\
\hline White Blood & $\left.\times 10^{9} / L\right)$ & $8.4(2.1)$ & $0.07-14.92$ & $24.3(5)$ & $16.4-43$ \\
\hline & Slope & & & & \\
\hline Regression $(\mathrm{pH})$ & $r$ & & & & \\
\hline & $\mathrm{p}$-value & & & & \\
\hline & Slope & & & & \\
\hline Regression $\left(\mathrm{PaO}_{2}\right)$ & $r$ & & & & \\
\hline & $\mathrm{p}$-value & & & & \\
\hline & Slope & & & & \\
\hline Regression $\left(\mathrm{PCO}_{2}\right)$ & $r$ & & & & \\
\hline & $\mathrm{p}$-value & & & & \\
\hline
\end{tabular}

concentration did not significantly differ in each subgroup. No difference was noted when the analysis was carried out in subgroups of patients with different values of platelets and hematocrit (Figure 1A).

Interestingly, a strong association was found between the value of WBC and decrease of glucose values $(r=-0.633, p<0.0001)$, but not between glucose and platelet count $(r=0.048 ; p=0.704)$ or hematocrit $(r=0.239 ; p=0.057)$ (Figure 1B). Glucose variations over time (from baseline to 2, 4, 6 and 8 hours after blood draw) was significantly accelerated in samples with WBC count $>15 \times 10^{9} / \mathrm{L}(\mathrm{n}=$ $10)$ as opposed to in those with WBC count $<15 \times$ $10^{9} / \mathrm{L}(\mathrm{n}=54)$.

\section{Blood gases parameters}

Overall, 77 blood gases samples were included in our analysis. The results, sorted according to WBC counts, are shown in Table II. No significant difference was found for baseline values of $\mathrm{pH}, \mathrm{pO}_{2}$ and $\mathrm{pCO}_{2}$ between the two groups.

A larger decrease of $\mathrm{pH}$ values over time was observed in samples with WBC count $>15 \times 10^{9} / \mathrm{L}$ $(n=45)$ compared to those with WBC count $<15 \times$ $10^{9} / \mathrm{L}(\mathrm{n}=32)$ (Table II and Figure 2A). However, no difference in $\mathrm{pO}_{2}$ and $\mathrm{pCO}_{2}$ values were noted between these two groups (Figure 2A).

The variations of blood gases values $\left(\mathrm{pH}, \mathrm{pO}_{2}\right.$ and $\mathrm{pCO}_{2}$ ) over time (i.e., at baseline and 60, 120 and $180 \mathrm{~min}$ afterwards) were analyzed with
Pearson's correlation, in which a significant association was found between time and $\mathrm{pH}$ in the two groups $(r=-0.204 ; p=0.0284$ and $r=-0.430$; $p$ $<0.0001)$, and $\mathrm{pCO} 2$ in the low leukocyte count cohort $(r=0.243 ; p=0.018)$. On the contrary no difference was observed for $\mathrm{pO}_{2}$ in both groups $(r=$ $-0.130 ; p=0.126$ and $r=-0.110 ; p=0.243$ ), and $\mathrm{pCO}_{2}$ in the high leukocyte cohort $(r=0.172 ; \mathrm{p}=$ 0.116 ). Notably, a highly significant association was noted between WBC count and $\mathrm{pH}$ changes over time $(r=-0.707 ; p<0.0001)$, but not between WBC count and variation of both $\mathrm{pO}_{2}(r=-0.167 ; \mathrm{p}=$ $0.121)$ or $\mathrm{pCO}_{2}(r=0.134 ; \mathrm{p}=0.348)$ values over time (Figure 2B).

\section{Discussion}

The stability of laboratory parameters in blood samples is an important matter of concern, since spurious variations occurring before testing may have a profound impact on clinical decision making and care management, thus ultimately jeopardizing patient safety. An important aspect that emerged from our study is that plasma glucose undergoes a substantial, time-dependent consumption in plasma samples displayed in even modest leukocytosis (i.e., $\sim 15 \times 10^{9} / \mathrm{L}$ ). The maximum allowable time before sample centrifugation shall hence be reduced in these patients since glucose values would become otherwise unreliable. The use of glycolysis inhibitors might also be mandatory in all patients with leukocytosis. However, the complete effect of fluoride on gly- 
colysis inhibition could take up to $4 \mathrm{~h}$ according to leukocytes values, and concentration of glucose in the blood tube may meanwhile considerably decrease (17). Alternatively, a comparison with glucose results obtained with a glucometer may be advisable in case of suspicious results.

Unlike previous studies $(18,19)$, we failed to observe an association between WBC count and variation of $\mathrm{pO}_{2}$ and $\mathrm{pCO}_{2}$, while we noted a significant association between WBC values and $\mathrm{pH}$, and this may be attributable to the fact that glucose metabolism by leukocytes may contribute to increased lactic acid production, thus generating acidosis.

In conclusion, the results of our study suggest that even modest leukocytosis (i.e., around $15 \times$

\section{References}

1. Cryer PE, Axelrod L, Grossman AB, Heller SR, Montori VM, Seaquist ER, et al. Evaluation and Management of Adult Hypoglycemic Disorders: An Endocrine Society Clinical Practice Guideline. J Clin Endocrinol Metab 2009 Mar 1; 94(3): 709-28.

2. Douillard C, Mention K, Dobbelaere D, Wemeau J-L, Saudubray J-M, Vantyghem M-C. Hypoglycaemia related to inherited metabolic diseases in adults. Orphanet J Rare Dis 2012 May 15; 7: 26.

3. Tarasova VD, Zena M, Rendell M. Artifactual Hypoglycemia: An Old Term for a New Classification. Diabetes Care 2014 May 1; 37(5): e85-6.

4. Nourrisson C, Batisse M, Sapin V, Bouvier D. Pseudo-hypoglycémie et hyperleucocytose : à propos d'un cas. Annales de Biologie Clinique 2010 Jul 1; 68 (4): 490-4.

5. Turcato G, Cervellin G, Bonora A, Prati D, Zorzi E, Ricci G, Salvagno GL, Maccagnani A, Lippi G. Red blood cell distribution width improves reclassification of patients admitted to the emergency department with acute decompensated heart failure. J Med Biochem 2018; 37: 299-306.

6. Levi M. Twenty-five million liters of blood into the sewer. J Thromb Haemost 2014 Oct; 12(10): 1592.

7. Milinković N, Ignjatović S, Šumarac Z, Majkić-Singh N. Uncertainty of measurement in laboratory medicine. J Med Biochem 2018; 37: 279-88.

8. Lippi G, Salvagno GL, Lampus S, Danese E, Gelati M, Bovo C, et al. Impact of blood cell counts and volumes on glucose concentration in uncentrifuged serum and lithium-heparin blood tubes. Clinical Chemistry and Laboratory Medicine (CCLM) 2018; 56(12): 2125-31.

9. Godignon M, Costes F, Sapin V, Bouvier D. A support to biological validation of oxygenation parameters. Annales de Biologie Clinique 2017 Nov 1; 75(6): 653-63.

10. Groenendaal F, Vooght KMKD, Bel F van. Blood Gas Values During Hypothermia in Asphyxiated Term Neonates. Pediatrics 2009 Jan 1; 123(1): 170-2.

11. Lippi G, Fontana R, Avanzini P, Sandei F, Ippolito L. Influence of spurious hemolysis on blood gas analysis. $\left.10^{9} / \mathrm{L}\right)$, which is frequently encountered in clinical and laboratory practice, may impair the stability of glucose and $\mathrm{pH}$ in blood samples. This would lead us to conclude that the results of these parameters should be perhaps accompanied by those of hematologic testing, namely the leukocyte count, to prevent clinical misinterpretation. In case of suspicious biochemistry results associated with high leucocyte levels, verification could be performed short-circuiting pre-analytical transport using glucometer or point of care device.

\section{Conflict of interest statement}

The authors stated that they have no conflicts of interest regarding the publication of this article.

Clinical Chemistry and Laboratory Medicine 2013; 51(8): 1651-4.

12. Liss HP, Piyne CP. Stability of Blood Gases in Ice and at Room Temperature. CHEST 1993 Apr 1; 103(4): 11202.

13. Katakura $Y$, Yamaguchi $Y$, Miyashita T, Idei M, Yoshida T, Matsuda $Y$, et al. Hyperleukocytosis Complicated by Intracerebral Hemorrhage and Spurious Hypoxemia: A Case Report and Literature Review. A A Case Rep 2017 Sep 15; 9(6): 159-61.

14. Rodríguez C, Pacreu S, Baldomà N, Sánchez S, Vilà E, Mases A. La leucocitosis extrema puede inducir a un diagnóstico erróneo de hipoxemia severa. Descripción de un caso. Revista Española de Anestesiología y Reanimación 2014 Jan 1; 61(1): 39-42.

15. Fox MJ, Brody JS, Weintraub LR, Szymanski J, O'Donnell C. Leukocyte larceny: A cause of spurious hypoxemia. The American Journal of Medicine 1979 Nov 1; 67(5): 742-6.

16. Horr S, Roberson R, Hollingsworth JW. Pseudohypoxemia in a Patient With Chronic Lymphocytic Leukemia. Respiratory Care 2013 Mar 1; 58(3): e31-3.

17. Lippi G, Nybo M, Cadamuro J, Guimaraes JT, van Dongen-Lases E, Simundic A-M. Chapter Four - Blood Glucose Determination: Effect of Tube Additives. In: Makowski GS, editor. Advances in Clinical Chemistry. Elsevier; 2018. p. 101-23.

18. Unlu $B$, Kume $T$, Emek $M$, Örmen $M$, Doğan $Y$, Şişman AR, Ergör G, Çoker C. Effect of blood cell subtypes lysis on routine biochemical tests. J Med Biochem 2018; 37: 67-77.

19. Prasad KN, Manjunath P, Priya L, Sasikumar S. Overcoming the problem of pseudohypoxemia in myeloproliferative disorders: Another trick in the bag. Indian Journal of Critical Care Medicine: Peer-reviewed, Official Publication of Indian Society of Critical Care Medicine 2012 Dec; 16(4): 210. 